DOI 10.31558/2307-2318.2018.3.11

УДК 338.26

Бруслиновська I.B., магістр, Донецький національний університет імені Василя Стуса Матвійчук B.І., к.е.н., доцент, Донецький національний університет імені Василя Стуса

\title{
ТЕОРЕТИЧНІ АСПЕКТИ ФОРМУВАННЯ ФІНАНСОВОЇ СТРАТЕГІЇ ПІДПРИЕМСТВА
}

В статті показано, що фінансова стратегія підприємства має провідну роль у стратегічному управлінні підприємством. Проаналізовано підходи вітчизняних та зарубіжних вчених до визначення поняття «фінансова стратегія підприємства» та запропоновано власне формулювання терміну. Розкрито місце та роль фінансової стратегії у стратегічному плануванні, встановлені зв'язки з функціональними стратегіями підприємства та із загальною стратегією. Виділено ключові етапи формування і реалізації фінансової стратегії підприємства та фактори, які впливають на вибір виду фінансової стратегії, з огляду на специфіку галузі та розміри підприємства. Охарактеризовано складові та інструменти формування фінансової стратегії підприємства. Визначено, що оптимально сформована та раціонально впроваджена фінансова стратегія сприяє підвищенню ринкової вартості підприємства та зростанню його прибутку.

Ключові слова: фінансова стратегія підприємства, стратегічне управління підприємством, функціональні стратегії, система стратегій підприємства.

\section{Бруслиновская И.В., Матвийчук В.И.}

\section{ТЕОРЕТИЧЕСКИЕ АСПЕКТЫ ФОРМИРОВАНИЯ ФИНАНСОВОЙ СТРАТЕГИИ ПРЕДПРИЯТИЯ}

В статье показано, что финансовая стратегия предприятия имеет ведущую роль в стратегическом управлении предприятием. Проанализированы подходы отечественных и зарубежных ученых к определению понятия «финансовая стратегия предприятия» и предложена собственная формулировка термина. Раскрыто место и роль финансовой стратегии в стратегическом планировании, установлены связи с функциональными стратегиями предприятия и с общей стратегией. Выделены ключевые этапы формирования и реализации финансовой стратегии предприятия и факторы, влияющие на выбор вида финансовой стратегии, с учетом специфики отрасли и размера предприятия. Охарактеризованы составляющие и инструменты формирования финансовой стратегии предприятия. Определено, что оптимально сформированная и рационально внедренная финансовая стратегия способствует повышению рыночной стоимости предприятия и росту его прибыли.

Ключевые слова: финансовая стратегия предприятия, стратегическое управление предприятием, функциональные стратегии, система стратегий предприятия.

\section{Bruslynovska I., Matviychuk V. THEORETICAL ASPECTS OF FORMATION OF THE ENTERPRISE FINANCIAL STRATEGY}

The article shows that the financial strategy of the enterprise has a leading role in the enterprise strategic management. The approaches of domestic and foreign scientists to the definition of «enterprise financial strategy» are analyzed and the own wording of the term is proposed. The place and role of the financial strategy in strategic planning are revealed. Established links with the company's functional strategies and the overall strategy. The key stages of formation and realization of the enterprise financial strategy are offered. The 
influence factors on the choice of the type of financial strategy are selected depending on the industry specifics and the enterprise size. The components and tools of financial strategy formation of the enterprise are characterized. It is determined that the optimally formed and rationally implemented financial strategy helps to raise the enterprise market value and increase its profit.

Key words: enterprise financial strategy, strategic enterprise management, functional strategies, system of enterprise strategies.

Постановка проблеми. Забезпечення сталого розвитку та розв'язання проблем економічної стабілізації діяльності вітчизняних підприємств на сьогодні безпосередньо пов'язані з фінансами. Фінансове управління виступає одним із видів функціонального управління і тісно взаємодіє із загальним стратегічним управлінням. За умов підвищення значущості вирішення проблем, що потребує забезпечення підприємства необхідними фінансовими ресурсами та ефективного управлінням ними, зростає значення фінансової стратегії як дієвого інструменту стратегічного управління фінансовими процесами підприємства.

Аналіз останніх досліджень і публікацій. Науково-теоретичні аспекти проблем стратегічного фінансового планування, питання розробки фінансової стратегії, іiі змісту та класифікаційних ознак відображені в публікаціях вітчизняних і зарубіжних авторів: В.І. Аранчія, І.О. Бланка, Ю.В. Дворнікової, О.П. Зорі, В.О. Зубенка, О.А. Кузнєцової, Ю.П. Лашка, О.І. Лозовської, П.М. Макаренка, О.В. Маковоза, А.І. Петрової, І.Й. Плікуса, Т.Є. Шевченка, О.В. Шраменка, В.А. Янковської та інших.

Виділення невирішеної проблеми. Незважаючи на значну кількість наукових робіт, присвячених тематиці фінансового управління, не існує єдиного, загальноприйнятого підходу до визначення сутності поняття «фінансова стратегія підприємства», її місця в системі управління підприємством, що значно ускладнює обгрунтування наукових рекомендацій щодо підвищення ефективності управління як підприємством взагалі, так і його фінансовими ресурсами зокрема.

Мета статті. Метою статті є розробка рекомендацій стосовно вдосконалення процесу формування фінансової стратегії підприємства на підставі визначення місця фінансової стратегії в системі стратегічного управління підприємством, іï складових та основних умов реалізації.

Виклад основного матеріалу. Ринкові перетворення, які відбуваються в Україні, обгрунтовують нові вимоги до побудови системи управління підприємством. Динаміка економічних процесів, загострення ринкової конкуренції знижують дієвість розроблених стратегічних планів, які не містять раціональних інструментів швидкого пристосування до змін внутрішнього та зовнішнього середовища підприємства.

За таких умов результативність діяльності будь-якого суб'єкта господарювання значною мірою визначається його фінансовою стратегією, яка, охоплюючи всі основні сфери його діяльності, що пов'язані з процесами формування необхідного обсягу фінансових ресурсів й координацією грошових потоків та їх використанням, відіграє важливу роль у створенні сприятливих умов для росту його ринкової вартості.

Необхідно відзначити, що фінансова стратегія - це відносно нове поняття у вітчизняній науці та практиці управління. Водночас слід підкреслити, що в зарубіжній літературі з фінансового управління (зокрема, американській та європейській) [2-7] поняття «фінансова стратегія» практично відсутнє, науковці оперують такими термінами, як «фінансове планування» $[2,4]$, «довгострокові інвестиційні 
рішення» $[3,6]$, «управління структурою капіталу» $[5,7]$. В стратегічному управлінні цей термін розглядається виключно як різновид функціональних стратегій.

Проведений аналіз різних поглядів й підходів науковців [2-7] до трактування сутності поняття «фінансова стратегія підприємства» дав змогу сформувати власне узагальнене його визначення.

На нашу думку, фінансова стратегія підприємства - це сукупність заходів щодо ефективного управління процесами залучення, розподілу та використання фінансових ресурсів суб'єктів господарювання, спрямованих на таку організацію фінансових відносин підприємства 3 контрагентами, яка дозволяє досягти встановлених цілей, насамперед - забезпечення зростання його ринкової вартості. Фінансова стратегія встановлює об'єкти, процеси, учасників ії формування і реалізації, механізми, що забезпечують досягнення цілей у рамках заданих обмежень, і через фінансові ресурси відіграє роль засобу координації інших функціональних стратегій.

Завданнями фінансової стратегії $\epsilon$ наступні: визначення способів проведення успішної фінансової стратегії та використання фінансових можливостей; визначення перспективних фінансових взаємовідносин із суб'єктами господарювання та фінансовими інститутами; фінансове забезпечення операційної та інвестиційної діяльності на перспективу; вивчення економічних та фінансових можливостей імовірних конкурентів, розробка та здійснення заходів щодо забезпечення фінансової стійкості; розробка методів управління та способів виходу із кризового стану.

В процесі розробки і реалізації фінансової стратегії варто враховувати динаміку як зовнішніх, так і внутрішніх факторів діяльності підприємства.

Фінансова стратегія підприємства згідно зі своєю стратегічною метою забезпечує виконання таких функцій[10]:

- визначення головної загрози з боку конкурентів, правильний вибір напрямків фінансових дій та маневрування для досягнення вирішальної переваги над конкурентами; створення та підготовка стратегічних резервів;

- ранжування та поетапне досягнення мети;

- формування та ефективне використання фінансових ресурсів;

• відповідність фінансових дій економічному стану та матеріальним можливостям підприємства;

- виявлення найефективніших напрямків інвестування та зосередження фінансових ресурсів на цих напрямках.

Фінансова стратегія передбачає визначення довгострокових цілей фінансової діяльності та вибір найефективніших способів їх досягнення. Цілі фінансової стратегії мають підпорядковуватися загальній стратегії економічного розвитку та спрямовуватися на максимізацію прибутку та ринкової вартості підприємства. Етапи розробки та реалізації фінансової стратегії представлені на рисунку 1 .

Вагомим етапом розробки фінансової стратегії $\epsilon$ оцінка iï ефективності. Ефективність реалізації фінансової стратегії (як результат - покращення фінансових показників діяльності підприємства, підвищення його ринкової вартості, максимізація прибутку, укріплення ділової репутації підприємства, підвищення якості управління фінансовою діяльністю його структурних підрозділів тощо) досягається за умови:

- узгодженості цілей, напрямків і етапів реалізації фінансової та загальної стратегії підприємства;

- адаптивність фінансової стратегії підприємства до прогнозованих змін у зовнішньому підприємницькому середовищі;

- реалізації розробленої підприємством фінансової стратегії щодо формування власних і залучених зовнішніх фінансових ресурсів $[9,10]$. 
Аналіз зовнішніх та внутрішніх факторів впливу на фінансову діяльність підприємства

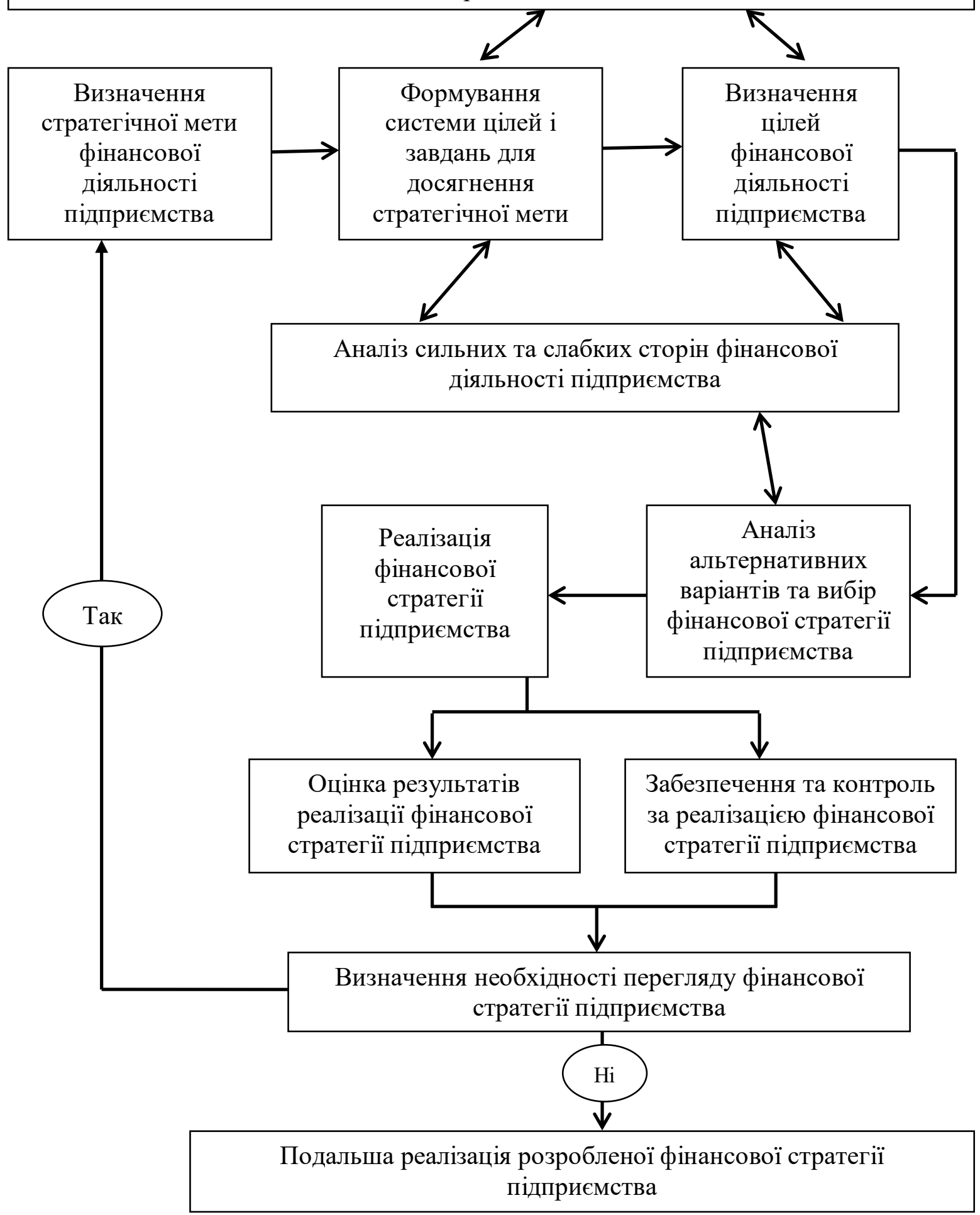

Рис. 1 - Послідовність етапів формування та реалізації фінансової стратегії підприємства 
Фінансова стратегія є елементом загальної корпоративної стратегії, що зумовлює розгляд iї сутності та змісту в контексті загального стратегічного менеджменту. Розробка фінансової стратегії підприємства має бути органічно вбудована в діяльність із підготовки і реалізації загальної стратегії. Щодо корпоративної стратегії фінансова має підлеглий характер, тому вона повинна бути узгоджена із цілями і напрямами корпоративної стратегії (прямий зв'язок). Зі встановлених основних стратегічних цілей першого рівня система фінансових цілей повинна «зростати» як особлива фінансова гілка загального дерева стратегічних цілей підприємства. Фінансова стратегія повинна мати управлінську орієнтацію, тобто бути спрямована на досягнення загальної мети управління щодо забезпечення сталого зростання вартості підприємства. 3 іншого боку, завдання фінансової стратегії істотно впливають на формування загальної стратегії розвитку підприємства, оскільки зміна ситуації на ринку спричиняє коригування фінансової, а потім, як правило, і загальної стратегії розвитку фірми - зворотний зв'язок (рис.2) $[2,10]$.

Динамічність факторів зовнішнього середовища спричиняє зміну й внутрішнього середовища підприємства. Це відображається на функціонуванні фінансового механізму управління підприємством. Тому в процесі діяльності підприємства необхідно корегувати параметри складових фінансової стратегії (рис. 3): стратегії формування фінансових ресурсів, інвестиційної стратегії, стратегії забезпечення фінансової безпеки, структурної стратегії, податкової стратегії, кредитної стратегії. Ці стратегії є основними компонентами фінансової стратегії.

Стратегія формування джерел фінансування - центральний компонент фінансової стратегії. Її метою $є$ створення оптимальних за обсягом, складом i структурою фінансових ресурсів, що забезпечують формування активів, необхідних для реалізації довгострокових планів господарської діяльності підприємства. Цілі, завдання і основні стратегічні рішення цього напряму мають бути спрямовані на фінансове забезпечення реалізації корпоративної стратегії.

Необхідність виділення інвестиційної стратегії як окремого компонента фінансової стратегії визначається значущістю інвестиційних процесів у підвищенні ринкової вартості підприємства, створенні стійких конкурентних переваг, забезпеченні динамічного зростання масштабів і диверсифікації бізнесу. Інвестиційна стратегія визначає пріоритетні напрями і форми інвестиційної діяльності, характер формування інвестиційних ресурсів і послідовність етапів реалізації довгострокових інвестиційних цілей, що забезпечують загальний розвиток підприємства.

Досягнення економічного ефекту за рахунок інвестицій визначається потенційною їх здатністю генерувати дохід у формі приросту інвестованого капіталу та інвестиційного прибутку. Оцінка інвестиційних проектів дозволяє визначити їх «стратегічну цінність», а саме - врахувати майбутні можливості підприємства залежно від реалізації поточних проектів. На практиці часто спостерігається паралельне, незалежне існування стратегічного менеджменту, із одного боку, i фінансового менеджменту, із іншого [9]. Тому при розгляді інвестиційних проектів від фінансового менеджера потрібна рівноправна участь у розробці його змісту.

Головна мета податкової стратегії - оптимізація сукупного податкового навантаження у поєднанні із зниженням рівня податкових ризиків підприємства. Ключовими елементами податкової стратегії є податкова облікова політика і політика мінімізації податкових ризиків. 
політичні,

громадські регулюючі норми; - Привабливість галузі та рівень

- Специфічні ринкові можливості загрози конкуренції

та

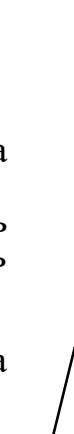

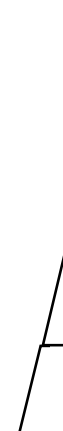

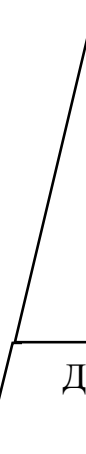

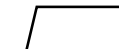

\section{Місія підприємства \\ $\downarrow$}

Обгрунтування актуальності

і формування цілей

Розробка забезпечуючих планів, політики, стратегії, бюджетів

Дії посилення конкурентних позицій та прибутковості існуючих сфер

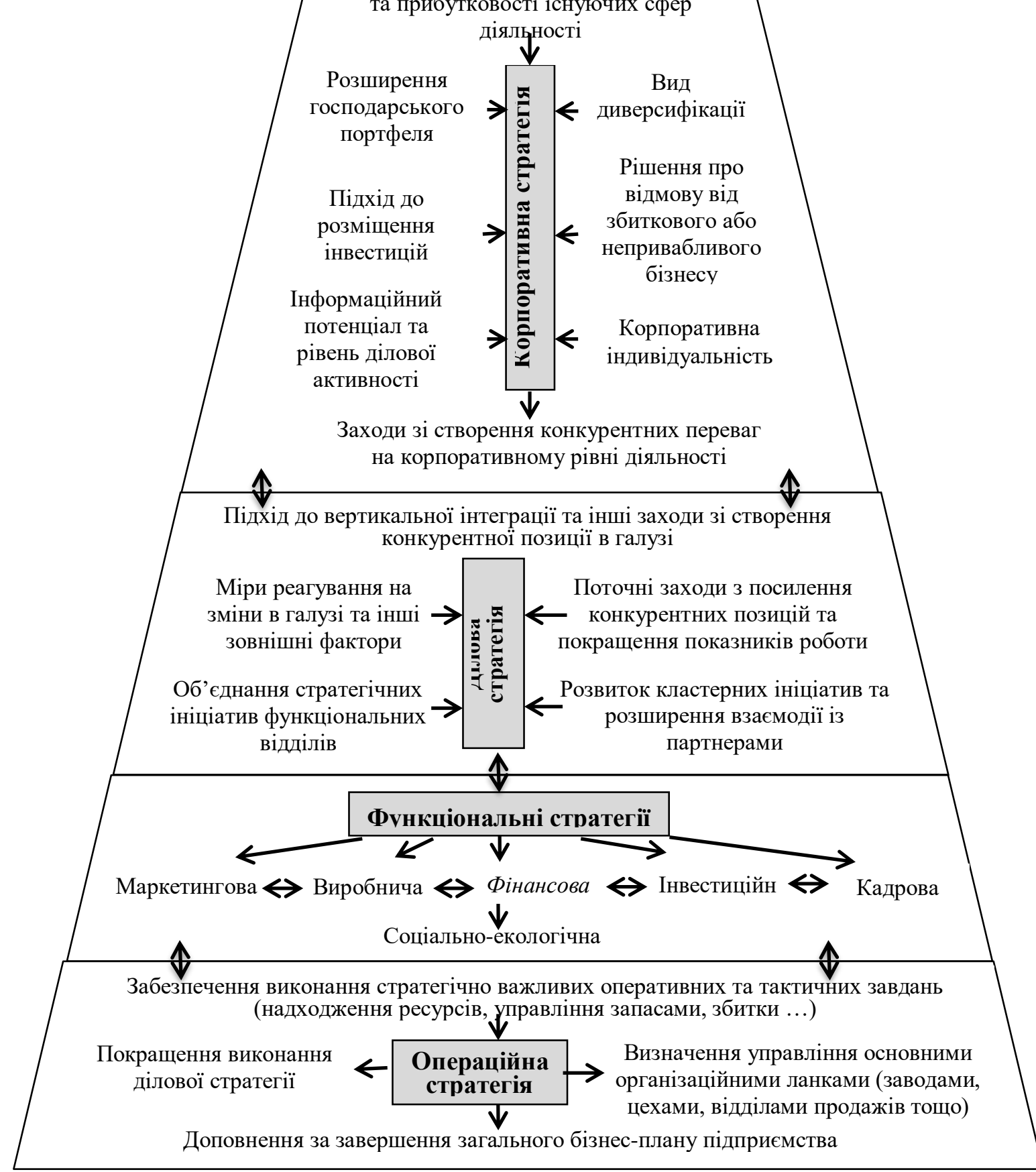

Рис.2 - Місце фінансової стратегії в системі стратегій підприємства
- Ц Цінності та

культура

підприємства

- Сильні та слабкі сторони підприємства, його конкурентні можливості 
Стратегія забезпечення фінансової безпеки об'єднує політику управління фінансовими ризиками; політику управління структурою капіталу; політику управління рухом грошових потоків. Цілі, завдання і основні стратегічні рішення цього напряму мають бути спрямовані на формування і підтримку основних параметрів фінансової рівноваги підприємства в процесі іï стратегічного розвитку через системи управління фінансовими ризиками. На кожній стадії реалізації фінансової стратегії необхідно здійснювати моніторинг ризиків із метою коригування ії параметрів.

Кредитна стратегія пов'язана із оцінкою обсягу фінансування із зовнішніх боргових джерел, вибором стратегії залучення позикових ресурсів та обгрунтуванням стійких джерел фінансування. Вона повинна бути орієнтована на вибір ефективних фінансових інструментів, розробку стратегії виведення боргових цінних паперів на фондовий ринок і обгрунтування емісії цінних паперів.

Під час розробки фінансової стратегії підприємства доцільно виділяти стратегічну складову, що відображає структурні зміни при стратегічному управлінні фінансовою діяльністю, - структурну стратегію. Вона пов'язана із вирішенням завдання оптимізації структури активів і капіталу підприємства, що корелює із кредитною й інвестиційною стратегіями через вартість авансованого в компанію капіталу, та із оптимізацією структури розподілу прибутку, що передбачає зміни в дивідендній і податковій політиці.

У межах стратегії підвищення якості управління фінансовою діяльністю основну увагу слід зосередити на розробці політики формування фінансової структури. Найбільш ефективним для реалізації фінансової стратегії $є$ створення системи центрів фінансової відповідальності. Це забезпечує гнучку адаптивність фінансової стратегії до змін i можливість застосування сучасних методів стратегічного фінансового планування.

У реальній ситуації при зміні факторів зовнішнього й внутрішнього середовища одна фінансова стратегія здатна трансформуватися в іншу. Тому компанія може реалізовувати одночасно декілька фінансових стратегій. Розробка і впровадження заходів фінансової політики в межах окремих стратегій дозволяє чітко визначити єдину концепцію розвитку підприємства в довгостроковій і короткостроковій перспективі, здійснити доцільний вибір механізмів і методів досягнення поставлених цілей.

До складу основних об’єктів фінансової стратегії підприємства входять:

- необоротні та оборотні активи;

- джерела фінансування (власний і позиковий капітал);

- сукупність фінансових ризиків;

- система управління фінансовою діяльністю підприємства;

- податкові платежі і податкові ризики;

- фінансові відносини між різними суб’єктами господарювання.

В основу розробки механізму реалізації фінансової стратегії покладено принципи: керованості, плановості, адаптивності, ієрархічності, безперервності розвитку. Механізм реалізації фінансової стратегії охоплює такі блоки: прогнозування розвитку підприємства на основі стратегічної вартості фінансової стратегії, розробка стратегічного фінансового плану, оцінка ризику фінансової стратегії та контроль. Центральним елементом механізму реалізації фінансової стратегії визначено стратегічне фінансове планування [2], оскільки процеси планування і формування стратегії підкоряються одним і тим же закономірностям економічного розвитку підприємства. 


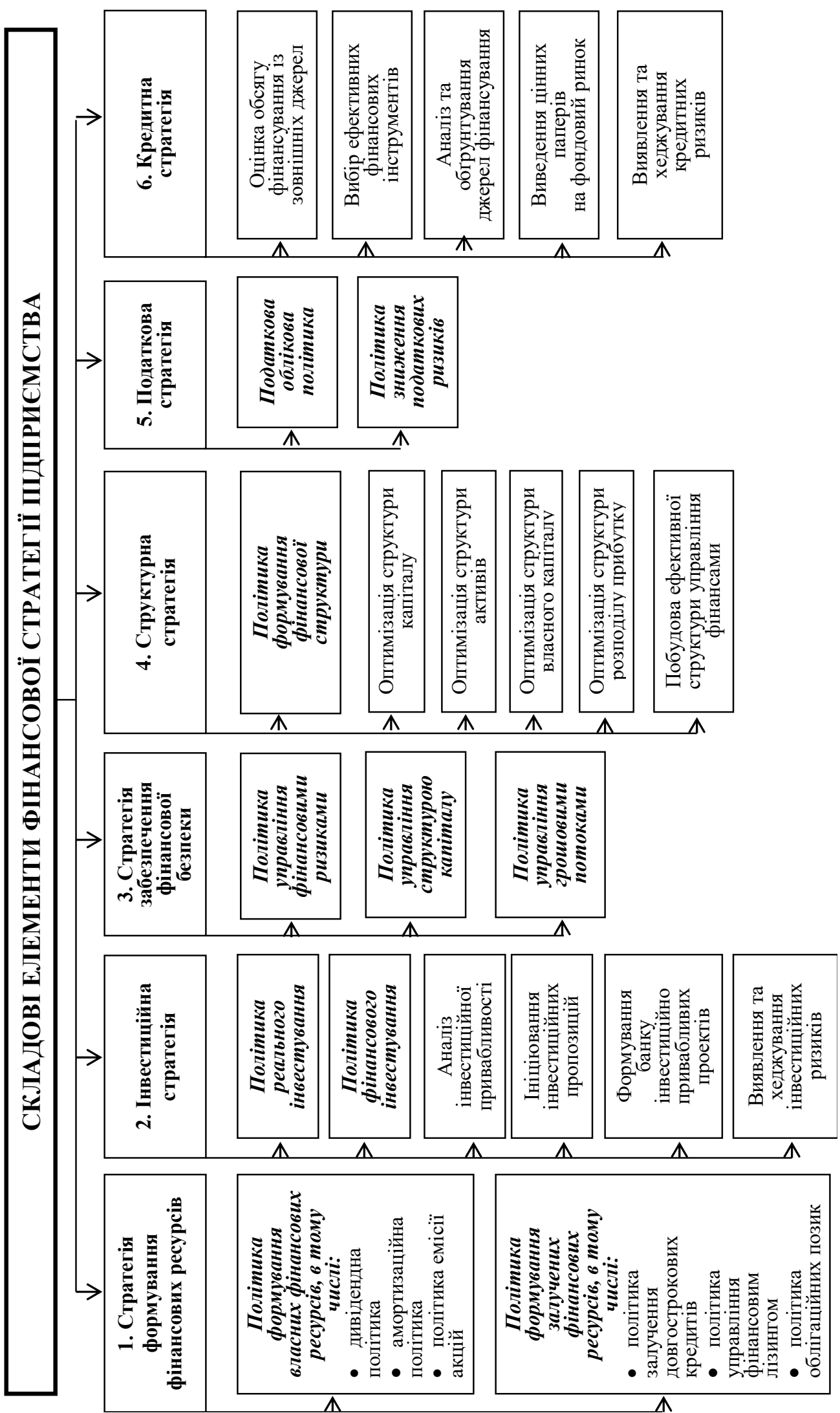

Рис. 3 - Складові фінансової стратегії підприємства та результати їх реалізації 
Процедура стратегічного фінансового планування передбачає наявність трьох компонентів: прогнозування системи збалансованих фінансових показників за принципом економічного компромісу - максимізації економічної вигоди; вибір найкращого варіанта стратегічного фінансового плану; оцінка структури стратегічних переваг окремих елементів та їх відповідності принципам оптимальності за Парето [8].

В цьому контексті пропонується застосовувати:

1) підхід до балансування індикаторів активу та пасиву фінансового плану через узгодженість трьох елементів активу: обсягу (потужності) виробництва та його структури; витрат; виручки від реалізації;

2) процедури модифікації показників пасиву фінансового плану за допомогою індикаторів максимізації вартості підприємства (рентабельність власного капіталу та його обіговість) і мінімізації ризику реалізації фінансової стратегії;

3) підхід до вибору альтернатив фінансових планів на основі результатів стратегічної діагностики;

4) ієрархічну модель фінансового планування.

Під час процесу розробки та реалізації фінансової стратегії підприємства визначальним фактором є масштабність галузі, в якій функціонує підприємство (рис.4).

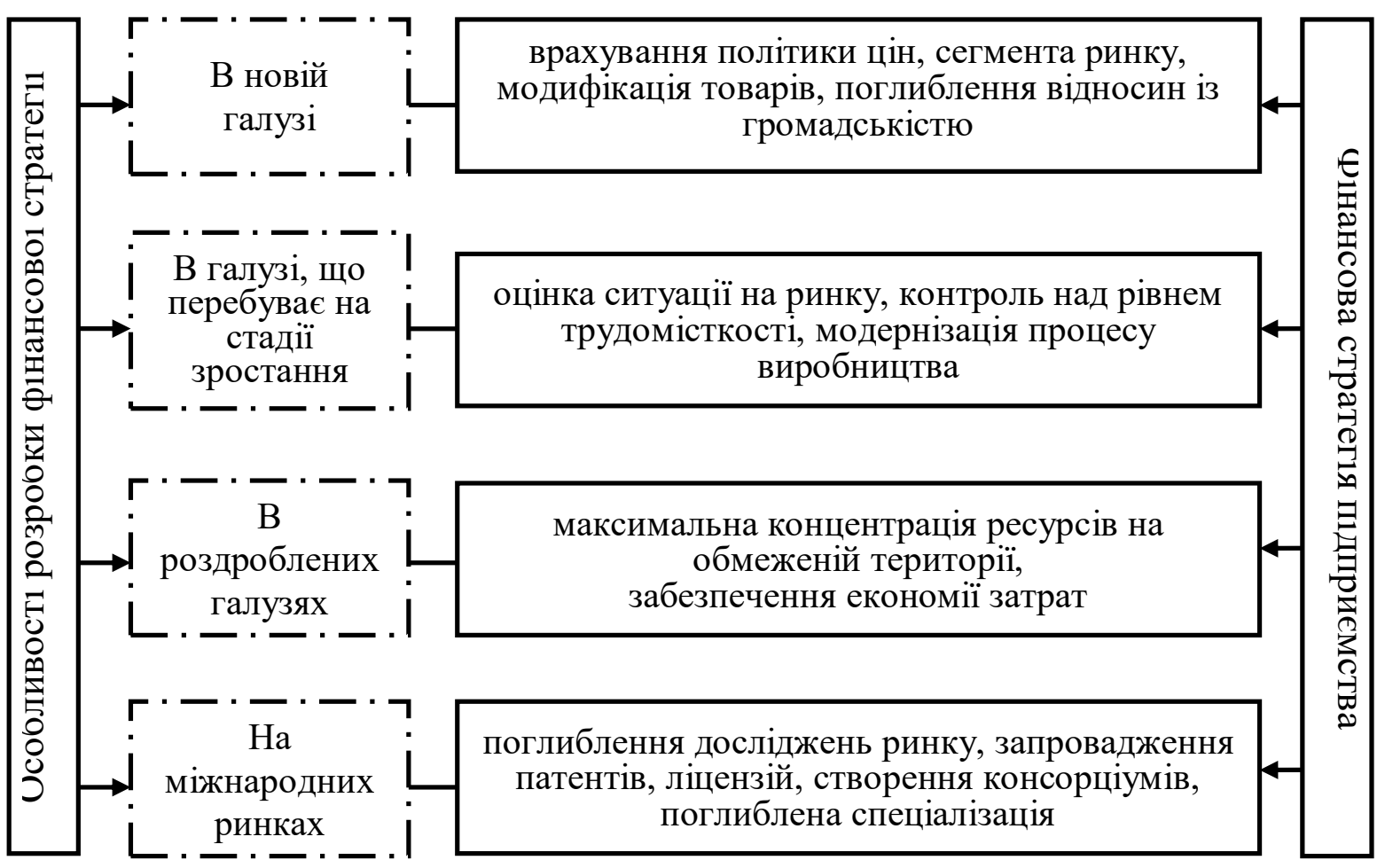

Рис.4 - Відповідність фінансової стратегії на рівні галузі та підприємства

В залежності від дій підприємства в галузі - вихід на ринок, лідерство, зміцнення, оборона - можна сформулювати зміст для фінансових стратегій як для визначеного плану дій. В цілому на рівні будь-якої галузі можна виділити:

- фінансову стратегію наступу, коли підприємство вперше входить в нову галузь і намагається викликати інтерес у більшості споживачів, формує свою репутацію, орієнтується на диференційовану продукцію; 
- фінансову стратегію підприємств-претендентів на лідерство, коли підприємство планує посилити свої конкурентні позиції, посилює увагу до дистриб'юторів, значно знижує рівень цін й активно просуває продукцію або товар;

- фінансову стратегію оборони та зміцнення, коли підприємству загрожують ринкові ризики, існує потреба в збереженні цін, покращанні якості продукції та необхідно інвестувати кошти в удосконалення технологічної бази;

- фінансову стратегію спаду й поступового припинення діяльності, коли підприємство має подбати про закриття каналів збуту, згортання виробничих потужностей, вилучення з обігу готівки, вихід з ринку.

Основними важелями успіху фінансової стратегії підприємства можна назвати: гнучкість цінової політики, створення авторитетної торгової марки, передові позиції в наукових пошуках, постійне вдосконалення технології. У разі відмови підприємства галузі від фінансової стратегії згортання діяльності, та під час виникнення загроз спаду, акцентують увагу на важливості недопущення стратегічних помилок: швидкого вилучення готівки 3 обігу, продовження участі у збитковій боротьбі, очікування покращення умов.

Наступним вагомим фактором для визначення типу фінансової стратегії є розмір підприємства. В.Д. Базилевич [1] наголошує, що за рівнем концентрації та централізації виробництва і капіталу підприємства поділяють на малі (дрібні), середні та великі (крупні). Згідно з цим, фінансова стратегія класифікується аналогічним чином (рис. 5). Чим більшим $\epsilon$ підприємство, тим складнішими $\epsilon$ мета, засоби іï досягнення, різноманітними є альтернативні варіанти фінансової стратегії та витрати.

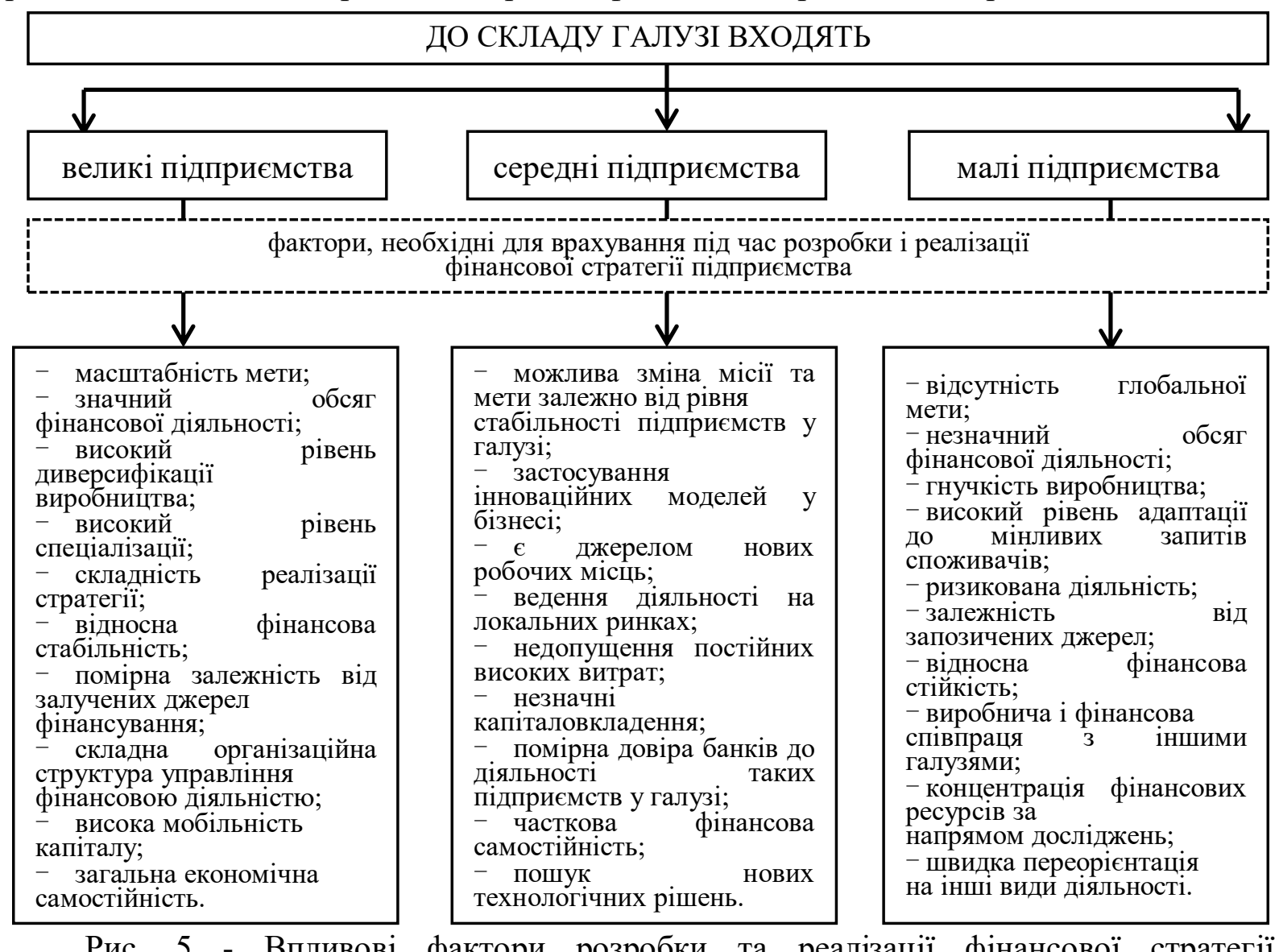

Рис. 5 - Впливові фактори розробки та реалізації фінансової стратегії підприємства залежно від його розміру 
Визначити єдиний підхід до вибору фінансової стратегії складно, адже кожен суб'єкт господарювання має свої особливості. Необхідно формувати таку фінансову стратегію, яка б мінімізувала ризики і сприяла збільшенню його прибутковості, підвищенню конкурентоспроможності та фінансової стійкості на ринку.

Необхідно зазначити, що фінансова стратегія не $\epsilon$ самостійно існуючою, вона тісно переплітається з іншими функціональними стратегіями, націлена на досягнення місії та постійний розвиток і вдосконалення діяльності суб'єкта господарювання, поглиблення кооперації та встановлення тісних міжгалузевих зв'язків. Види фінансової стратегії є індикаторами іiі багатогранної діяльності, розкривають далекоглядні плани підприємства щодо фінансування, зміни фінансової політики, надають інформацію про стійкість і розвиненість галузі, потребу в дотаціях. Інформація, зібрана в процесі розробки фінансової стратегії підприємства та результати діяльності суб'єкта господарювання, отримані в результаті реалізації фінансової стратегії, дозволять розкрити потенціал підприємства, сприяючи підвищенню ринкової вартості та максимізації прибутку.

Висновки та перспективи подальших досліджень. Підсумовуючи результати проведеного дослідження, можна зазначити, що фінансова стратегія підприємства $є$ надзвичайно важливою складовою стратегічного планування. Серед функціональних стратегій вона заслуговує на особливу увагу, адже, узгоджуючись із загальною стратегією підприємства, виступає ефективним інструментом перспективного управління його фінансовою діяльністю. Однак між фінансовою та загальною стратегіями часто виникають суперечності, тому що процедура розробки грунтується на різних передумовах: загальна стратегія орієнтується на визначення основного напряму розвитку підприємства, а фінансова - на бажаних результатах його фінансової діяльності. Перспективи подальших досліджень полягають в розробці концепції вдосконалення формування та реалізації фінансової стратегії підприємства 3 урахуванням кон'юнктури й тенденцій розвитку ринку, на якому функціонує конкретне підприємство, та факторів ризику, що зумовлені різними трансформаційними процесами, які сьогодні відбуваються в Україні.

\section{СПИСОК ВИКОРИСТАНИХ ДЖЕРЕЛ}

1. Базилевич В.Д. Метафізика економіки : наук. повідомлення / В.Д. Базилевич // Вісник Київського нац. ун-ту ім. Тараса Шевченка. - 2006. - С. 64-65.

2. Бланк I.А. Фінансовий менеджмент: навчальний курс. / I.А. Бланк. - 2-е видавництво, перероб. і доп. - К .: Ельга, Ніка-Центр, 2013.

3. Васенко В. К. Фінансова діагностика і санація діяльності підприємства: моногр. / В. К. Васенко; Східноєвроп. ун-т економіки і менедж. - Черкаси, 2009. - 203 с.

4. Власова К.Э. Финансовая стратегия: теоретические основы и методика разработки URL: https://sibac. info/conf/manag/ia/51429.

5. Гавриленко П.П. Удосконалення фінансового менеджменту в контексті інноваціого розвитку підприємств /П.П. Гавриленко//Науковий вісник НЛТУ України. 2015. - Випуск 25,4. - С. 199-204.

6. Гаркуша Н.М. Моделі і методи прийняття рішень в аналізі та аудиті: Навч. посіб. / [Н.М. Гаркуша, О.В. Цуканова, О.О. Горошанська]; за ред. Н. М. Гаркуша; 2-ге вид., стер. -К. : Знання, 2012. —591 с. -(Вища освіта XXI століття).

7. Гасанов С. С. Фінансова санація. Теоретичні та прикладні аспекти / С. С. Гасанов, А. М. Штангрет, Я. В. Котляревський, О. В. Мельников, Т. С. Мінаєва; Держ. 
навч.-наук. установа «Акад. фінанс. упр.». - К. : ДННУ «Акад. фінанс. упр.», 2013. $308 \mathrm{c}$.

8. Історія економічних учень: Підручник: У 2-х ч. - 3-тє вид., випр. і доп. Затверджено МОН / За ред. В.Д. Базилевича. - К., 2006. - 1157 с.

9. Кірейцев Г. Г. Фінансовий менеджмент: навч. посіб. - К.: Центр навчальної літератури, 2004. - 531 с.

10. Міщенко А. П. Стратегічне управління: навч. посіб. - К.: Центр навчальної літератури, 2004. - 336 с. 